\title{
DNA Repair
}

National Cancer Institute

\section{Source}

National Cancer Institute. DNA Repair. NCI Thesaurus. Code C16513.

Enzymatic restoration of DNA structure after chemical, radiation, or spontaneous damage. 